\title{
DANGER IN HERITAGE BY FORGETFULNESS. VICENTE SANCHO ARCHITECTURE
}

\author{
C. Burguete-Gil ${ }^{1, *}$ \\ ${ }^{1}$ Departamento de Composición Arquitectónica, Universitat Politècnica de València, Valencia, Spain - carburgi@alumno.upv.es
}

Commission II - WG II/8

KEY WORDS: Lost heritage, Modernisme, Sancho Fuster, Valencia, heritage dangers

\begin{abstract}
:
We are used to considering the risks on the architectural heritage as direct attacks on it, such as abandonment, degradation of materials, ... However, the loss of said assets can be caused simply by ignorance of them. This is the case of Vicente Sancho Fuster and his work. Vicente Sancho Fuster worked during the first decade of the 20th century in Valencia. His work is part of the trend of Valencian Art Nouveau, along with Vicente Ferrer and Demetrio Ribes. However, he is barely known due to his sudden death at age 35. His work continues being virtually unknown today, even by architects, despite its enormous interest and significance for the history of local and national Art Nouveau architecture. The greatest impediment to the study of his creation is the location of the works he created, because the references found are marked by inaccuracy and lack of data. As a result we find both: works attributed to Vicente Sancho Fuster that are not his own, and works attributed to other authors but in which his signature appears. At the same time, when his work is compared with some of the Art Nouveau buildings which have been protected by municipal law, it can be shown that both deserve to have the same consideration.
\end{abstract}

\section{INTRODUCTION}

\subsection{Introduction}

During the last years of the 19th century and the first years of the 20th century, an artistic tendency started to develop in Europe. This tendency consisted of a renewal that tried to create a new style. This new style was a break with the most deeply rooted styles of the time, the academicism (Historicism or Eclecticism) and the breakaway (Realism or Impressionism) (Benito, 1981). This movement was the clearest attempt to join art and technique, leaving movements throughout Europe that picked up on this trend (Sembach, 1990). This implied that the works resulting from all these trends presented important characteristics, not only in their design but also in their construction and materials. This style showed different currents depending on the country where it developed. Architectural Art Nouveau was born in Belgium; where it took its name of "New Art". Two of its most important representatives were Victor Horta, who built the Tassel House and the Solvay House in Brussels, and Van de Velde. In France, this style received the same name. One of its exponents was Hector Guimard and his most representative work was the metro stations in Paris. When the new style arrived in Germany, it was named as Jugendstil. An example of it was August Endell's Hackesche Höfe in Berlin. Another movement was Modern Style in England, represented by Mackintosh who designed the new building of the Glasgow School of Fine Arts. The Nieuwe Kunst in the Netherlands and Liberty or Floreale in Italy were other examples of the different names of the Catalan and Valencian so called Modernisme. But one of most recognized currents was Sezession which developed in Austria. Its greatest exponent was Otto Wagner, who visited Madrid in 1904 for the 6th International Architects Congress. His work influenced the architects trained in Barcelona in the early years of the 20th century, including Vicente Sancho and his friends Vicente
Ferrer and Demetrio Ribes. In Barcelona, Modernisme had its greatest importance with architectural production such as the Palau de la Música Catalana designed by Lluís Domènech i Montaner and Antoni Gaudí's extensive work, in which he developed a personal language.

\subsection{Background}

Art Nouveau came late to Valencia, brought by architecture graduates who studied in Barcelona. This style was first introduced by José Manuel Cortina Pérez, who began his studies in Barcelona in 1884, and travelled to Madrid in 1890 to obtain the title of architect at Madrid Architecture School. After Cortina, there were two waves of architects who brought the new style. The first one was formed by who graduated in 1897 and 1898: Francisco Mora (Jimenez, 1987; Magro, 2017), Carlos Carbonell (Valles, 2017) and Manuel Peris Ferrando. The second wave was formed by the architects Vicente Sancho, Demetrio Ribes (Aguilar, 2007) and Vicente Ferrer (Mestre, 2010). This generation licensed in Barcelona between 1902 and 1904. Five of these architects developed their work for more than forty years leaving buildings worthy of being classified as assets of local interest and being preserved (Exp. 03001/2004/342). But, one of them, Vicente Sancho Fuster, carried out his work for only 6 years, from 1904, when he finished his studies, to 1910, when he died. Despite this short period of time, he left 40 records only in Valencia, including apartment buildings, mortuary architecture, commercial facades and industrial pavilions (Vegas López-Manzanares, 2004). In 1912, one of the most famous Art Nouveau architects from Valencia, Francisco Mora, published a paper in the journal: Arte y Construcción (ISSN:1887-5351) praising the work of his friend Vicente Sancho (Mora, 1912). After this paper, the architect and his work fell into oblivion and there were no more memories about him.

\footnotetext{
* Corresponding author
} 
This paper is going to show, through Vicente Sancho's architectural production, some of the risks that heritage has to face, especially, the vulnerability that architectural production has when it is consigned to oblivion. This circumstance repeats over time, and architects, whose work was forgotten, have been rescued and considered as great geniuses. One example is Guastavino, who was overlooked until he was rediscovered a few years ago (Vegas López-Manzanares, 2017). But, sometimes this rescue arrives late and most of the architect's work has been destroyed, modified or simply lost.

\section{HAZARDS TO HERITAGE}

Cambridge Dictionary defines heritage as "features belonging to the culture of a particular society, such as traditions, languages, or buildings, which were created in the past and still have historical importance" (Cambridge, 2019). Heritage needs to be preserved to be enjoyed by the following generations (Ley 4/1998; Prats, 2001; Romero, 2017; Nebreda, 2018). But the first thing to preserve heritage is to identify the key characteristics that make it important enough to be preserved. In accordance with this need, the city council of Valencia started the process to approve the Structural Catalogue of Protected Buildings and Spaces in 2010 (Decreto 62/2011), finishing this process in 2015. As the decree approving this catalogue (exp. 03001/2004/342) reads: "The catalogue aims to complement the determinations of the general plan, in the aspects related to the conservation and protection of the cultural heritage deserving special protection. Its purpose is to identify those assets that have outstanding heritage values (...) in order to analyze them and offer adequate protection to ensure their conservation and preservation over time." In the section dedicated to the 2nd District, there are some buildings with the denomination Local interest assets (BLR, Bien de relevancia local). Most of the buildings included in this list are related to Modernisme. But this style is only recognized if it belongs to a famous architect such as Gaudi and Cortina. Nevertheless it is more than that. There are many buildings which haven't yet obtained the recognition they deserve and they have simply been forgotten. This situation leads us to the loss of key elements that explain Valencian modernist architecture, not only in design terms but in construction ones. This architecture has different influences marked by what the architects received during their training.

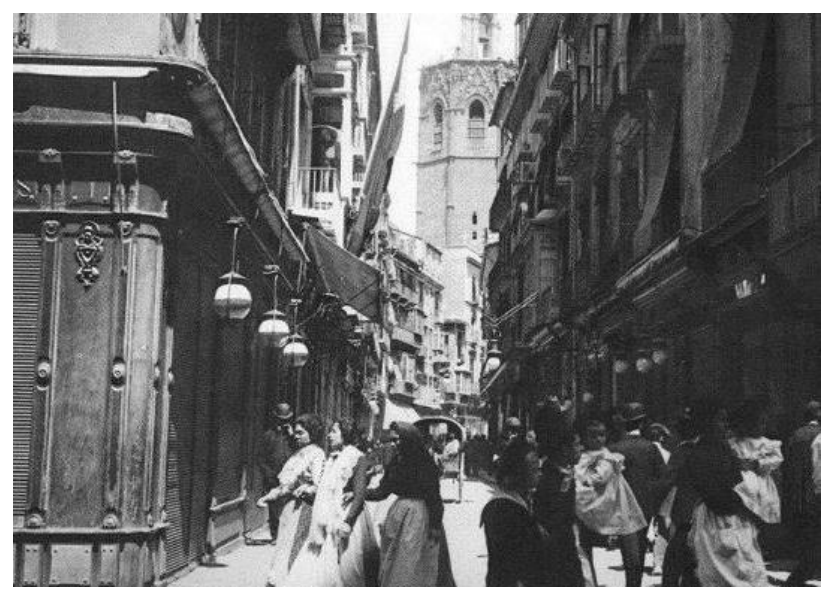

Figure 1. Old and disappeared Zaragoza Street in Valencia.

Fundación Goerlich archive. Source:

https://www.lasprovincias.es/valencia-ciudad/calledesaparecida-centro-valencia-20180914132801nt.html?ref=https:\%2F\%2Fwww.google.com $\% 2 \mathrm{~F}$
The first influence and the most visual one, is about decoration and the second one is related to the way of geometrizing the shapes of the buildings (Vegas López-Manzanares, 2004). This group of elements shows that Valencian modernist architecture presents a series of own characteristics that can be lost in time. That is the reason why it can be said that oblivion and lack of recognition causes different dangers to heritage. Demolitions of the Plaza de la Reina in Valencia destroyed a bustling area of shops in the city (Lita J, 2018) (Figure 1). With them, besides the shopping area, two of Vicente Sancho's designs disappeared, the cover and showcase of M. Serra's shop (exp. policía urbana. 3564/1905/4) and a showcase in Burriels cake shop (exp policía urbana 8537/1909/8). The shopcases and the canopies are the showiest elements of the Modernisme.

But these haven't been the only demolitions carried out in Valencia that have destroyed Vicente Sancho's architectural legacy. The demolitions to create space for the expansion of the museum Pio XII, destroyed Domingo Gracía's house, built in 1906 by Vicente Sancho (exp. Policía urbana 17565/1906/21). This house could be a sample of a traditional single family house in Modernisme terms and gave the opportunity to study this kind of building; due to the fact that all of the protected edifices are residential. An example of an unprotected residential house is the one designed by Vicente Sancho, La casa de los pajaritos (shallows building) (Figure 2). In 1909, Vicente Sancho projected a house at 36, Gran Vía Marqués del Turia, for his wife Matilde Pons. This house was not designed as a single edifice, since it belonged to the project of three constructions that formed a single group. The building at 36 was mimetically repeated at number 40 . In fact, with one single project, a building licence was requested for the two edifices. Between them, he planned a third building which served as the axis of symmetry of the complex. He could not erect this last building due to his sudden death. His widow commissioned its construction to the architect Antonio Ferrer Gómez, who presented the licence application in 1911 with the drawings made by Vicente Sancho. This building has the same characteristics as some of the buildings inscribed in the Structural Catalogue of Protected Buildings and Space of Valencia such as Chapa Building, Ferrer Building or la casa de los dragones design by Cortina. However, it has not been included in the catalogue of protected buildings of Valencia. For this reason it has been substantially modified. It still preserves its original facade, but its interior has been totally modified. The building doesn't keep its original distribution, internal decoration or even construction. The uses in the ground floor have changed so they show new elements that don't fit with the facade such as metal garage doors.

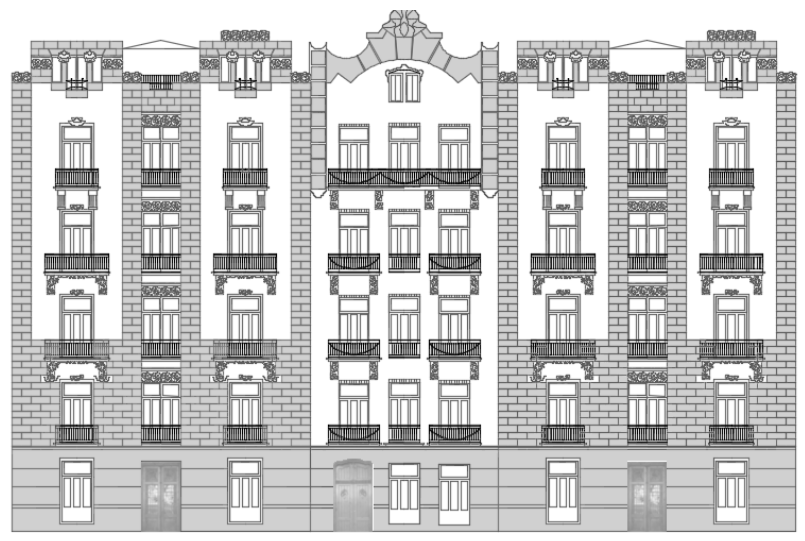

Figure 2. Facade. La casa de las golondrinas. Source: Own drawing. 
La casa Rotglà (Rotgà building) is one of the first works that Vicente Sancho made. His work consisted in the refurbishment of the building. The artistic resources used on the facade were repeated in several of his works such as the cottage house of Lamberto Lacasa in Turís and one building in Main Street of Burriana. Besides these resources, the building has some special details worthy to be named. One of the most peculiar is that the original door and the modernist one can be observed next to each other. But none of these details can be detected, because the ground floor has been taken by a restaurant whose motley decoration of marine themes has cancelled out any other type of detail. On the other hand, the building has lost its identity because of the degradation of its surroundings. Most of the original buildings have been demolished and reformed with no criteria. For this reason, the building remains alone and lacks context in the city as it can be observed in figure 3 .

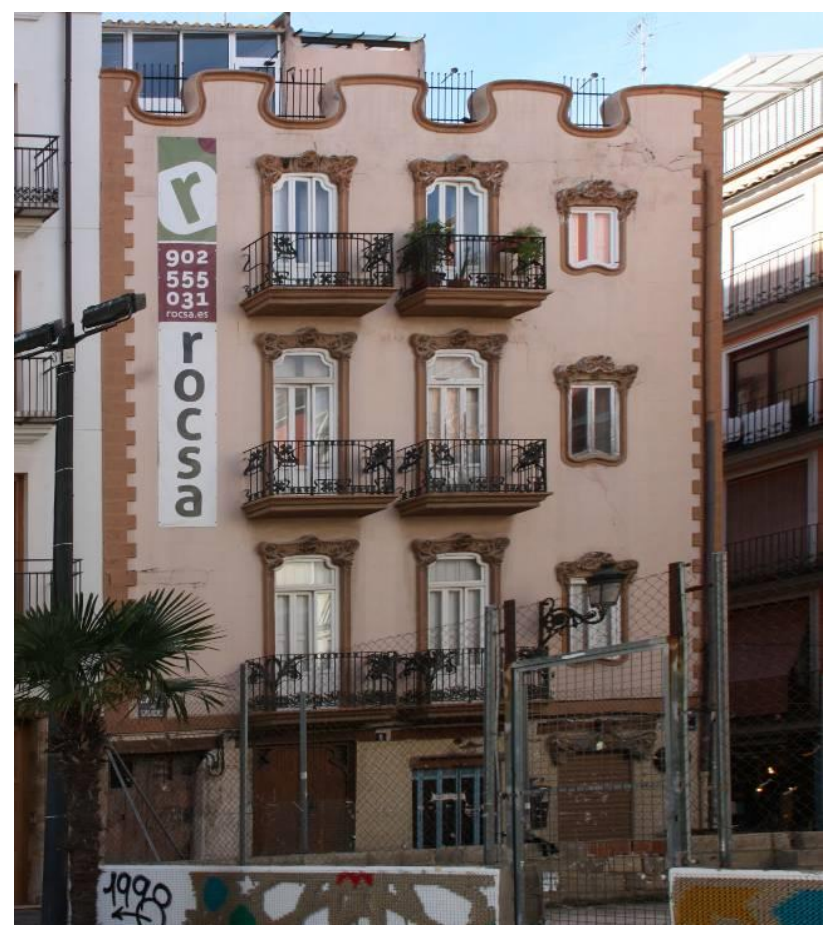

Figure 3. Facade. Casa Rotglà. Sourse: Own source.

La casa Espert (Espert building) is affected by the same circumstances as la casa Rotglà. In 1908, Vicenta Espert, commissioned Vicente Sancho to undertake the refurbishment of the building placed in Pelayo Street. This project covered changes both, inside and outside. The holes of the facade were moved to obtain a grid. And the holes on the ground floor were modified to give more importance to this floor. Inside, the changes gave more representation to the staircases and provided healthier features such as ventilation and lighting as shown in the drawings in figure 4 . The project of this building was an example of the health changes that were introduced by Modernisme. In the facade, Vicente Sancho followed the characteristics of its designs: the decoration around the holes and the holes into a grid. A large part of the decoration was made by the balcony ironwork and the carpentry design. But nowadays all these works have disappeared. The building disappears behind publicity and advertisement in the ground floor shops (Figures 5 and 6), holes have been modified and carpentry has been removed. The smart facade (Figure 7) has become a grotesque mix of nonsense. The original wooden frame from the lookout has been substituted by a metal one and the holes closed by walls. The balconies have also been changed. These changes make the building lose the original quality of its design. However, the loss not only affects the aesthetics of one building, but it has also prevented the possibility of studying the construction of those elements, such as carpentry that could be as interesting as Gaudi's carpentry in building such as El Capricho in Comillas; or the ironwork of the balconies.

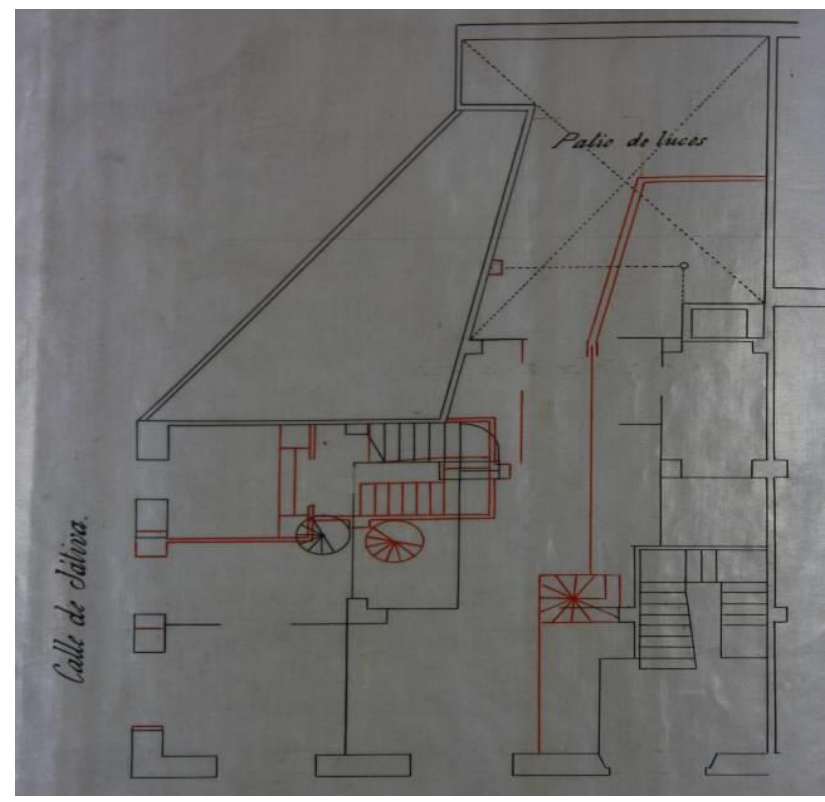

Figure 4. Original state in red on the drawings of the reform. Original. Municipal historical archive of Valencia. Source: Own photograph.

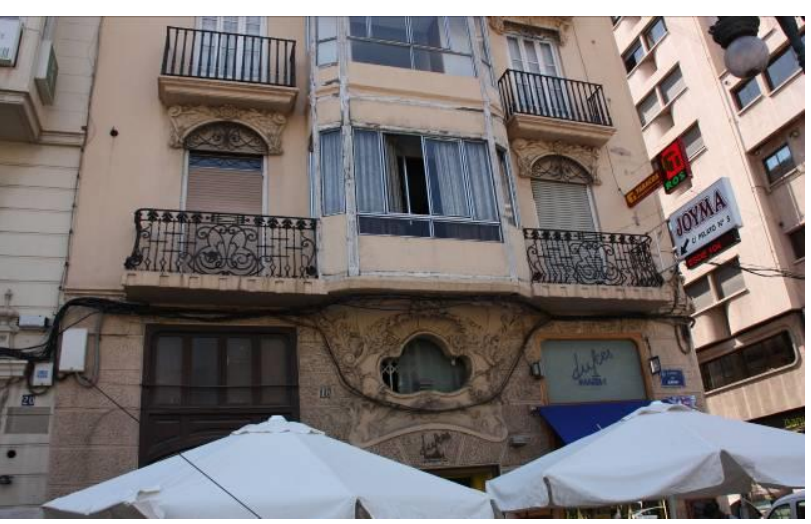

Figure 5. Facade. Casa Espert. Xativa Street. Sourde: Own photograph.

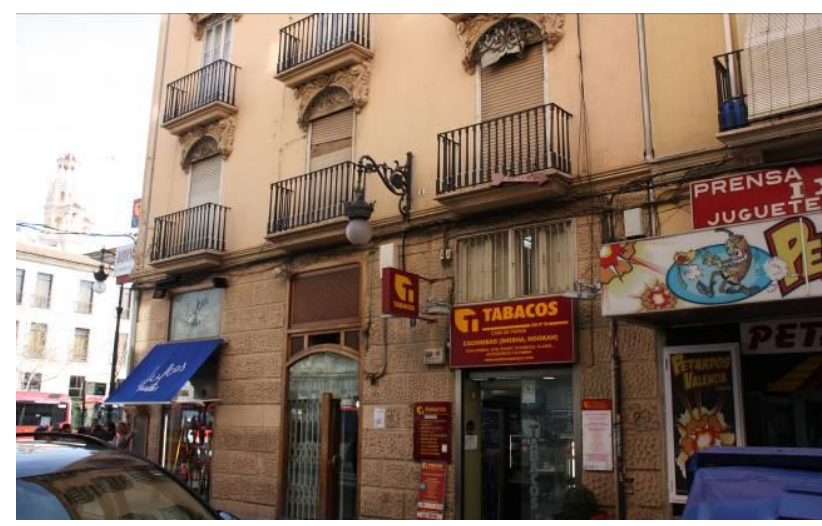

Figure 6. Facade. Casa Espert. Pelayo Street. Source: Own photograph. 


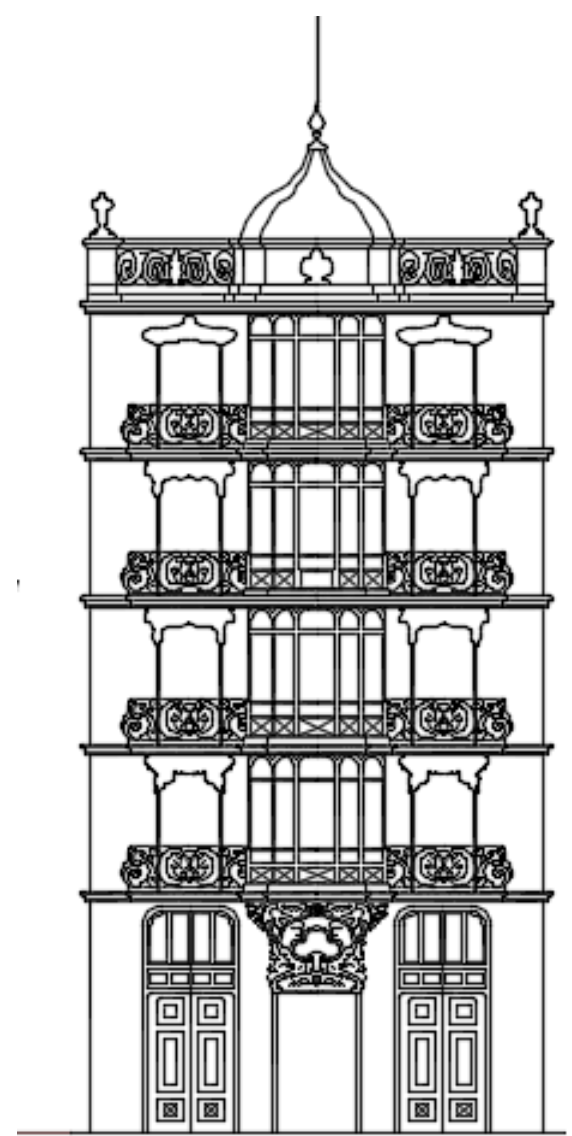

Figure 7. Original facade. Casa Rotglà. Source: Own drawing.

Another danger that forgotten architecture has to face is the substantial modifications to which they are subjected by the lack of enhancement. An example is the huge change that María Aliño's pantheon suffered. It was built in 1094 following the design of Vicente Sancho as it is shown in figure 8. It showed not only a great and delicate work of sculpture, but also impressive ironwork.

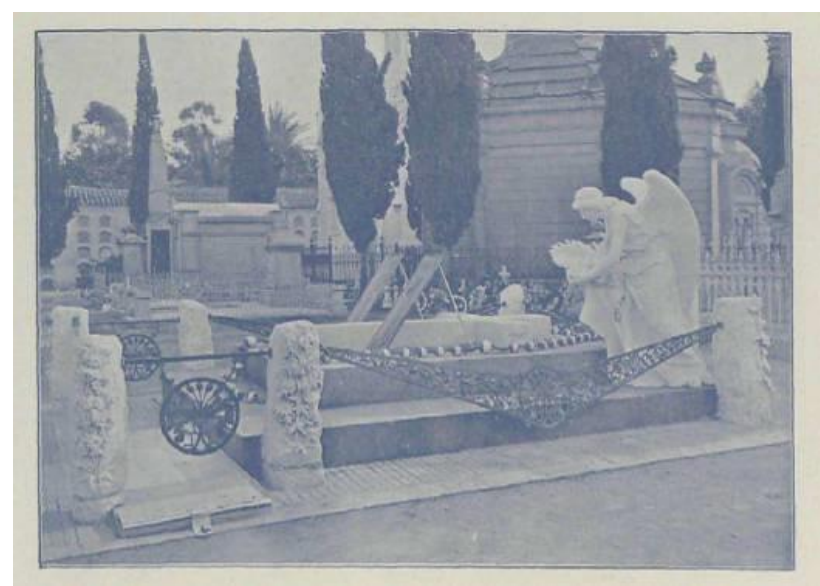

Figure 8. Original Maria Aliño pantheon. Cemetery of Valencia. Source: Arquitectura y Construcción journal, 1912, number 242 , figure 33.

This pantheon has been completely modified. And the decorating sculptures and ironwork elements have been used like decoration trinkets, placed meaninglessly (Figure 9).

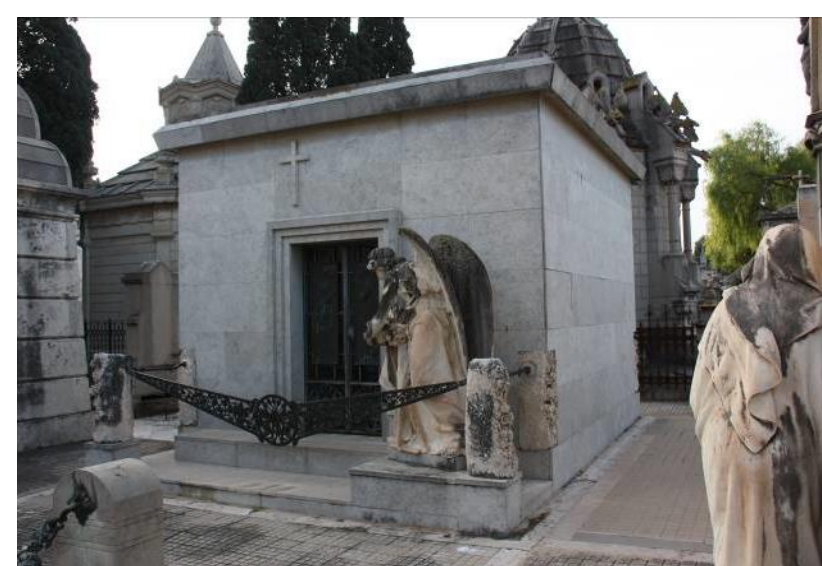

Figure 9. Current Maria Aliño pantheon. Cemetery of Valencia. Source: Own photograph.

Destruction or refurbishments are not the only dangers that unprotected buildings have to face. One hazard can be simply the loss of reality. It takes place in Carles family's pantheon. It is attributed to Vicente Cerda, the architect who happears in the municipal file (exp 9 / EII-B 1904-1905. But observing the pantheon, Vicente Sancho's signature is located in the construction, showing that he took part in this work, as it can also be deduced by his design and construction (Figures 10 and 11).

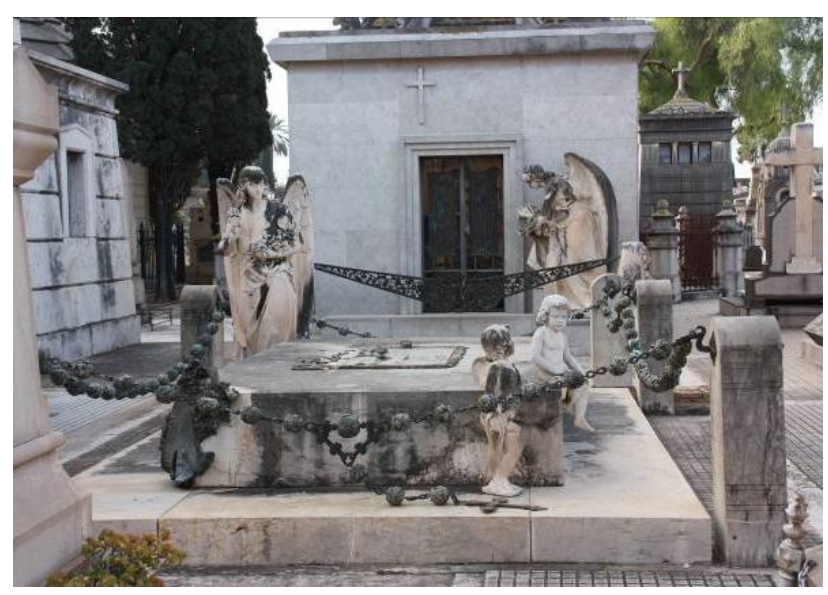

Figure 10. Carles family pantheon. Cemetery of Valencia. Source: Own photograph.

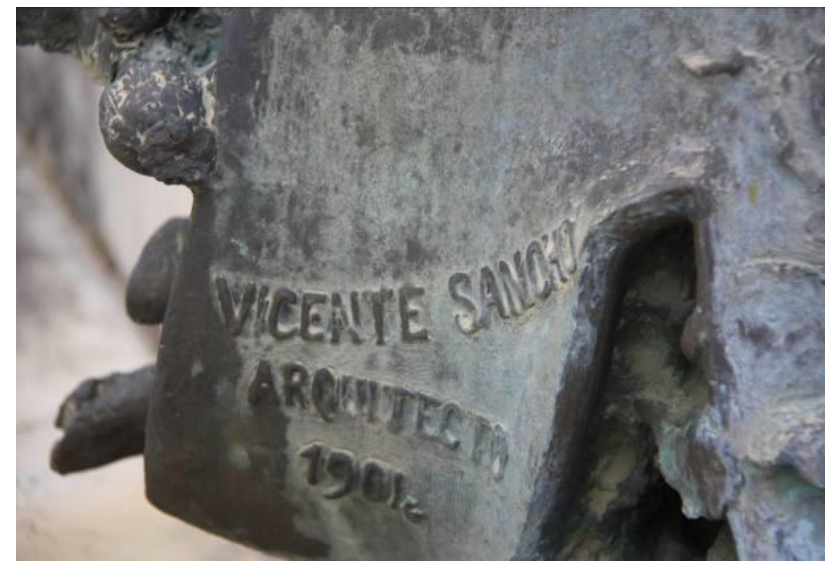

Figure 11. Signature of Vicente Sancho in Carles family pantheon. Cemetery of Valencia. Source: Own photograph. 
The hazards of unprotected buildings are not only the action over them, but the different actions around them. Change of street numbering, construction or removal of buildings and clogging the city lead to not being able to locate some of Vicente Sancho's constructions, such as the one he built in Felix Pizcueta Street without number or the house for Matilde Pons in Jesus Road. But the worst of all is when heritage is consigned to oblivion. One of the most aggravating examples is the British Cemetery in Valencia, placed in front of the main access to the Valencia Central Cemetery and never seen. (Figure 12)

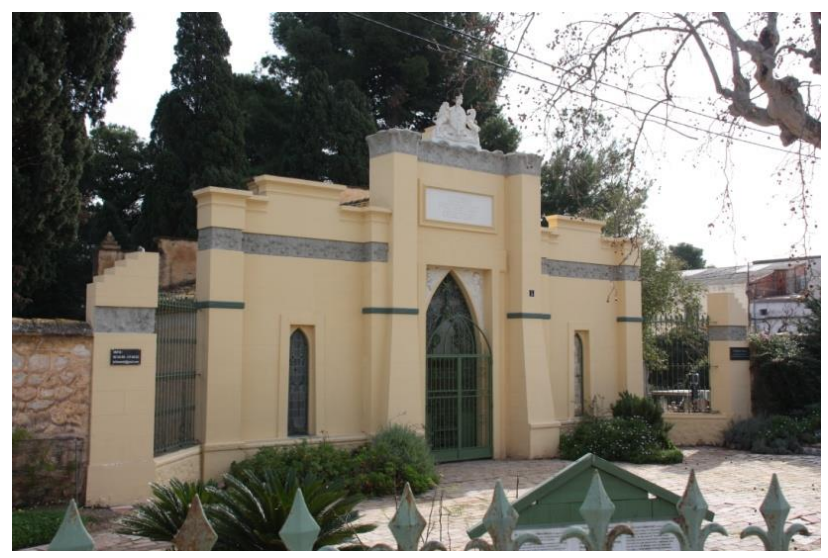

Figure 12 Facade. British Cemetery of Valencia. Source: Own photograph.

Two architects acted in this construction, Antonio Martorell until 1896 and Vicente Sancho who carried out his work in 1907. In the Municipal Historical Archive of Valencia there is only the project of Antonio Martorell that includes the execution of the perimeter wall and the closing gate. In the drawings, no buildings are included. So, taking the references made by Francisco Mora and Daniel Benito Goerlich, it can be assumed that Vicente Sancho designed and built the existing edifices. They consist of the entrance portico and the chapel. The main facade is neo-Gothic, and in the entrance and in the chapel, stained glass windows with floral motifs can be found. They were made with exquisite taste and they are similar to the ones in the door of la casa Rotglà in the Bordadores Street. But in this place, the stained glass windows are in terrible condition (Figure 13).

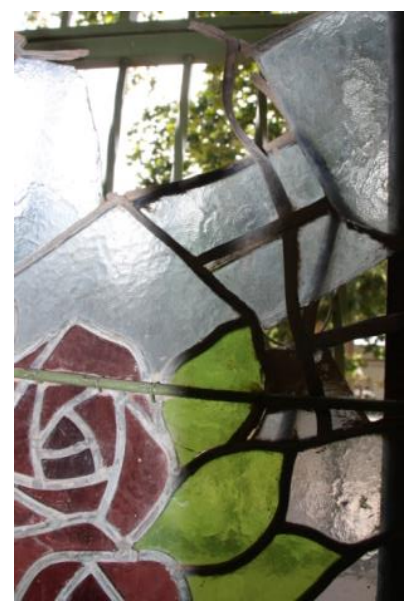

Figure 13. Stained glass window. British cemetery of

Valencia. Source: Own photograph.

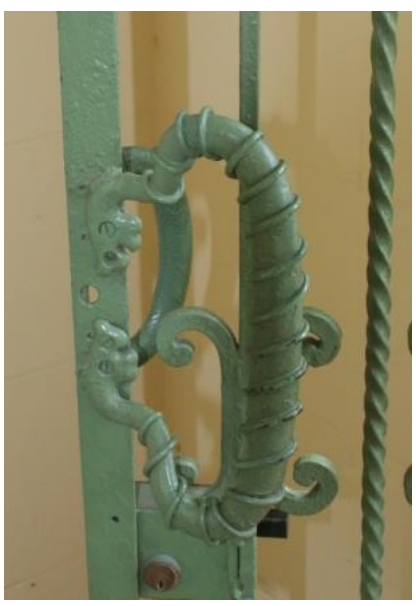

Figure 14. Metallic decorative motifs. British cemetery of Valencia. Source: Own photograph.
These windows haven't totally disappeared due to the interest of a group of British people who try to maintain their cemetery for sentimental reasons. Other very interesting details in this building are the metallic decorative motifs placed all around. An example is the enclosure opening handle formed by a dragon that "guards" it (Figure 14). It was beautifully worked and set on the door. In the chapel, there are bats with similar characteristics to those found in the Risueño family pantheon. This animal is closely related to the city of Valencia and, on this occasion, it could have been used by Vicente Sancho to bring deceased foreigners closer to this new city, where they lived and where their remains rest. Besides the decoration motifs, the building has great interest because of the composition of its facade and the way the architect resolved the disparity between interior uses and the symmetry of the facade. Despite all these facts, the building has been abandoned for years and it's totally unknown. Only luck has meant that it hasn't been destroyed, losing an important part of our heritage. A heritage built in Valencia but of international relevance because of its use.

\section{CONCLUSION}

Art Nouveau is an artistic style developed throughout Europe, with special characteristics in each country. Differences are due to the way the artist understood the changes that this style brought. In Spain, talking about Modernisme, is talking about Gaudí. But this style was carried out by more architects, some famous and others unknown. In Valencia, preserved buildings are those which belong to famous architects such as Cortina and Demetrio Rives. There are more edifices which are worthy of protection, but they have been left out of the Structural Catalogue of protected buildings and spaces of Valencia. And for this reason they are degrading and Valencia is losing an important part of its heritage. This loss is not only about its appearance but its constructive techniques, special use of materials and the union with its environment. But that is not all. Even the protection of those buildings included in the catalogue is carried out only in compositional terms, neglecting fundamental characteristics of Modernisme, such as its carpentry, interior decoration, stairs ... This usually happens because they have already been lost. The abandonment of many of the buildings included in this stream leads to the loss of elements and features that were developed during this time. And therefore they can be studied in detail.

One special case is Vicente Sancho Fuster's architectural production. His buildings distinguish the characteristics of Art Nouveau, especially in the floral decorations he used in some buildings, and the Sezession with the geometrization of shapes, symmetry and order. He has been ignored for years because of his early death, but he deserved recognition and respect from his colleagues. As Francisco Mora explained in the Arte $y$ Construcción journal in 1912: Even today we always remember him and we admire any of his works, (...). He died young, but he could leave, auspiciously for art, examples of good work as evidenced by numerous buildings he built (..)

But la casa de las golondrinas is not the only modernist building forgotten by the council of Valencia. There are others, such is the one shown in figure 15, la casa del punt de ganxo, which contains all the characteristics highlighted in the protected buildings such as composition, symmetry and special decoration (CTACV, 2007). In conclusion, the helplessness that many modernist buildings suffer, due to the fact that their architects have not been recognized for different reasons, leads to the disappearance of heritage. Some buildings don't disappear totally but they are reformed in a way that they lose 
the characteristics that defined their style and the materials specially designed for their construction such as carpentry or ironwork. At the same time, their surroundings are altered so that the buildings are lost in the city and affected by indirect attacks such as loss of perspiration from their walls due to excess paving of the surroundings with non-porous materials.

But the great interest that these buildings have make them worthy of protection, maintenance and study in order to preserve the characteristics that they have for future generations.

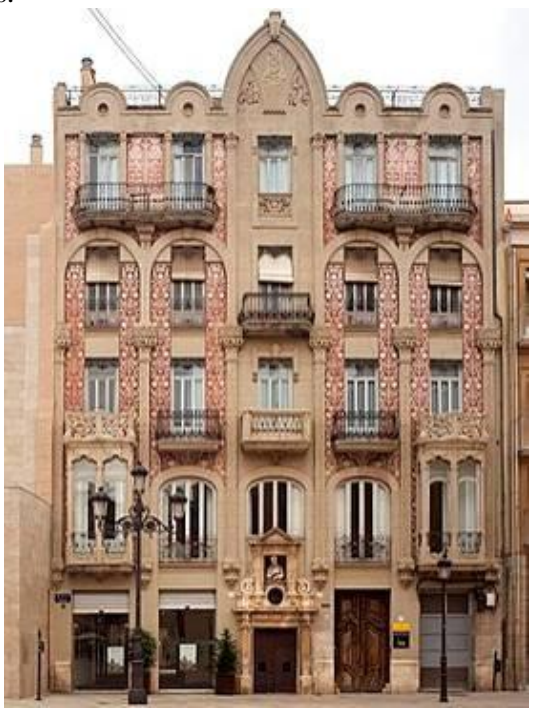

Figure 15. Casa de punt de ganxo. Source:

https://es.wikipedia.org/wiki/Casa_del_Punto_de_Gancho

\section{REFERENCES}

Aguilar, I. 2007. La Mirada de l'Arquitecte. Demetrio Ribes i la seua càmera estereoscópica (Catalogo exposición). Ed. Universitat de Valencia. Valencia. EG, 2007, mayo-septiembre 2007. 310 p. ISBN: 978-84-370-6745-2.

Benito, D. 1981. La arquitectura del eclecticismo en Valencia. Vertientes de la arquitectura valenciana entre 1875 y 1925. Ayuntamiento de Valencia. Valencia.

Cambridge dictionary developed team. 2019. Definition of heritage from Cambridge Business English Dictionary (c) Cambridge University Press.

COACV developed team, 2007. Guía de Arquitectura de Valencia. Colegio Territorial de Arquitectos de la Comunidad Valenciana. Valencia

Decreto 62/2011, de 20 de mayo, del Consell, por el que se regula el procedimiento de declaración y el régimen de protección de los bienes de relevancia local. DOGV núm. 6529 de 26.05.2011. 2011/6066.

Exp. 03001/2004/342. Catálogo de bienes y espacios protegidos. Resolución de la Consellera de Infraestructuras, territorio y Medio Ambiente, de 20 de febrero de 2015 relativo al Catálogo $n^{\circ}$ 118. 2015/15362. 23/6/2015. pp. 5 - 33

Exp. 3564/1905/4. Archivo histórico municipal de Valencia. Permiso para colocar portada y escaparate. M. Serra. Calle Campaneros, 1. Valencia. 1905
Exp. Policía urbana 8537/1909/8. Archivo municipal de Valencia. Permiso para sustituir puerta. Plaza de la Reina, 1. Valencia. 1909.

Exp. Policía urbana 17565/1606/21. Archivo municipal de Valencia. Permiso para construir una casa. Domingo García. Camino de Vuelta de Ruiseñor, 6. Valencia. 1906

Goerlich, D. 1981. La arquitectura del eclecticismo en Valencia. Vertientes de la arquitectura valenciana entre 1875 y 1925. Ayuntamiento de Valencia. Valencia

Jimenez, F. 1987. Un proyecto inédito de Francisco Mora Berenguer, en Valencia/España (1925-1928): Mercado para Carlet. Informes de la Construcción, Vol. 39 n. ${ }^{\circ}$ 392, noviembre/diciembre, 1987. Pag 27-35

Ley 4/1998, de 11 de junio, del Patrimonio Cultural valenciano. BOE» núm. 174, de 22 de julio de 1998, páginas 24768 a 24793

Lita J. 2018. La calle desaparecida del centro de Valencia. LAS PROVINCIAS. Valencia. 15 septiembre 2018

Magro, I. 2017. Legado de Francisco Mora Berenguer. $1^{\text {er }}$ Ciclo de conferencias MACVM. UPV. Valencia. I.S.B.N. 978-84946462-5-6

Mestre, M. 2010. Viena en la arquitectura de Vicente Ferrer Pérez (1874-1900). Revisión de su obra. ARS LONGA. Núm. 19, 2010 pp. $171-183$.

Mora, F. 1912. Arquitecto D. Vicente Sancho. Arte y Construcción journal, $\mathrm{n}^{\mathrm{o}} 242$ septiembre. pp. 259-260. (ISSN:1887-5351)

Nebreda, L. 2018. La protección del patrimonio históricoartístico durante la Segunda República: Análisis de documentación legal, en Revista General de Información y Documentación 28 (1), 213-241.

Prats, J. 2001. Valorar el patrimonio histórico desde la educación: Factores para una mejor utilización de los bienes patrimoniales. Aspectos didácticos de las ciencias sociales. Zaragoza: ICE de la Universidad de Zaragoza, 2001.

Romero, C. 2017. Algunos apuntes sobre la aplicación del patrimonio histórico y artístico. Tribuna 13-12-2017. https://elderecho.com/algunos-apuntes-sobre-la-aplicacion-delpatrimonio-historico-y-artistico

Sembach, K. 1990. Modernismo. La utopía de la reconciliación. Benedikt Taschen. Köln. 1990. pp 9

Torreño, 2005. Arquitectura y urbanismo en Valencia. Colección Tierra viva. Valencia. 2005. pp 104.

Valles, J.M. 2017. Edificio Chapa (2019) TFG. Proyecto de interiorismo. Departamento de Expresión Gráfica Arquitectónica. ETSEE. UPV.

Vegas López-Manzanares et al., 2017. El arquitecto Rafael Guastavino (1842-1908): obra en cuatro actos. Ars Longa (26) pp. 1-12

Vegas López-Manzanares, F. 2004 La arquitectura de la exposición regional valenciana de 1909 y nacional de 1910. Valencia. UPV 